\title{
Changes in agglutinating antibody titers and serum proteins of immunized eels
}

\author{
Riichi Kusuda, Kenji Ono, Fulvio Salati \\ Fish Disease Laboratory, Faculty of Agriculture, Kochi University, Nankoku, Kochi 783, Japan
}

\begin{abstract}
A formalin-killed cell (FKC) preparation of Edwardsiella tarda was injected once intramuscularly into eels to study changes in agglutinating antibody titers and serum proteins. Blood samples were taken at $1,2,3,5,8$, and 12 wk after immunization. Agglutinating antibody titers were determined, and serum protein changes were investigated by electrophoresis and filtration on Sephadex G-200. At $25^{\circ} \mathrm{C}$, eels produced agglutinating antibodies against $E$. tarda $F K C$ within 1 wk, with the maximum response occurring at $3 \mathrm{wk}$ after immunization. There were no significant differences between immunized and non-immunized eel sera using cellulose acetate and polyacrylamide electrophoresis or immunoelectrophoresis. By gel filtration of the serum, 4 fractions were obtained but only the first showed specific agglutinating activity against $E$. tarda FKC. This activity was lost after treatment with 2mercaptoethanol. The results suggest that in eels, the substance responsible for specific agglutinating activity in the serum corresponds in certain properties to human IgM.
\end{abstract}

\section{INTRODUCTION}

The indiscriminate use of chemotherapeutics in aquaculture and the appearance of drug-resistant strains of fish pathogens suggest that the use of vaccines may be a better approach to protecting fish against bacterial infections. There are many reports on fish vaccination but the majority deal with practical questions of vaccine efficacy. To produce an effective vaccine, studies on the immune response of fish are very important. Edwardsiella tarda, a bacterium with world-wide distribution, causes a systemic disease of cultured eels in Japan and Taiwan (Wakabayashi \& Egusa 1973). Edwardsiellosis is one of the principal problems in greenhouse cultured eels. Vaccines consisting of various E. tarda antigen preparations have been tested in eels on a number of occasions (Song \& Kou 1981, Salati et al. 1983, 1984, Salati \& Kusuda $1985,1986)$. The purpose of these studies was to investigate the protective properties of various anti-E. tarda vaccines, administrated by various routes. Data are available on other bony fish antibodies but only a few fundamental studies have been done on eel antibody production (Fine et al. 1963, Hara 1975, Nagai \& Sugai 1977 ) in spite of the economic importance of eels.

In this study, to investigate the primary immune response of eels against Edwardsiella tarda infection, fish were immunized with formalin-killed E. tarda cells and the resulting antibody production and changes in the serum proteins were examined by electrophoresis and gel filtration.

\section{MATERIALS AND METHODS}

Experimental animals and aquaria. Japanese eels Anguilla japonica weighing $120 \mathrm{~g}$ were obtained from an eel farm in Kochi Prefecture, Japan, and kept at $25^{\circ} \mathrm{C}$ in $60 \mathrm{l}$ tanks with recirculating, aerated, and filtered well water. The eels were maintained in the tanks for a few days before the start of the experiment to accustom them to the new conditions. The fish were fed during the experiment with a commercial balanced feed.

Microorganism. Edwardsiella tarda, Strain EF-1, was originally isolated in June 1979 from the kidney of a diseased Japanese eel cultured in Fukuroi, Shizuoka Prefecture, Japan.

Preparation of antigen. Lyophilized EF-1 was precultured in Brain Heart Infusion (BHI, Difco, Detroit, MI, USA) broth at $37^{\circ} \mathrm{C}$ for $18 \mathrm{~h}$, then inoculated into a fresh sample of the same medium and incubated at $37^{\circ} \mathrm{C}$ for $24 \mathrm{~h}$. The bacteria were recovered by centrifugation at $10000 \times g$ for $30 \mathrm{~min}$ and resuspended in physiological saline containing $0.5 \%$ formalin. After incubation at $20^{\circ} \mathrm{C}$ for $48 \mathrm{~h}$, the cells were centrifuged 
and washed with physiological saline. The formalinkilled cells (FKC) were resuspended at a concentration of $10 \mathrm{mg} \mathrm{ml}^{-1}$ in physiological saline and stored at $5^{\circ} \mathrm{C}$.

Immunization. Eels were injected intramuscularly with $0.1 \mathrm{ml}$ of the FKC preparation. A control group was injected with $0.1 \mathrm{ml}$ sterile physiological saline.

Blood sampling. After 1, 2, 3, 5, 8, and $12 \mathrm{wk}, 4$ eels from each group were bled. The blood was stored overnight at $4^{\circ} \mathrm{C}$ and the serum collected by centrifugation at $1000 \times g$ for $20 \mathrm{~min}$ and stored at $-35^{\circ} \mathrm{C}$.

Titration of serum antibody. The serum agglutinating antibody titer against Edwardsiella tarda FKC was determined by the microtiter method (Nowotny 1969) with incubation for $2 \mathrm{~h}$ at $25^{\circ} \mathrm{C}$ and overnight at $4{ }^{\circ} \mathrm{C}$.

Electrophoresis. Cellulose acetate electrophoresis was performed using Separax (Fuji Film, Tokyo, Japan) and barbital buffer ( $\mathrm{pH}$ 8.6). One microliter of pooled serum sample was electrophoresed at $0.8 \mathrm{~mA} \mathrm{~cm}^{-1}$ for $30 \mathrm{~min}$. The membranes were stained with Ponceau 3R and destained with $3 \%$ acetic acid. The color density of the stained bands on the membranes was read at 505 $\mathrm{nm}$ in a Chromatoscanner Shimazu CS-900. Polyacrylamide gel electrophoresis was performed by the method of Davis (1964) and Ornstein (1964).

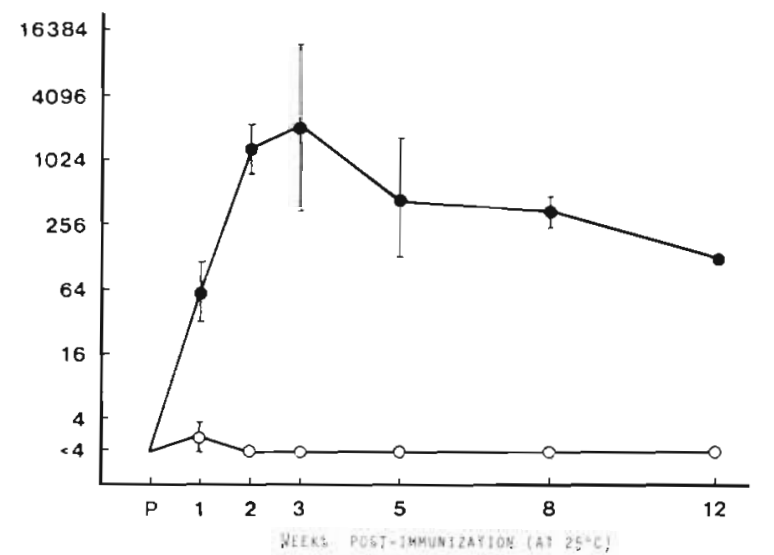

Fig. 1. Anguilla japonica. Changes in agglutinating antibody titer of immunized and non-immunized eel sera. $P$ : preimmunization; (•) FKC, (O) control. Bars: \pm standard deviation

The gel for immunoelectrophoresis was prepared with $1 \%$ lonagar No. 2 (Oxoid, London, England) in barbital buffer ( $\mathrm{pH} 8.6$ ). Electrophoresis was carried out at $4{ }^{\circ} \mathrm{C}$ at $3 \mathrm{~mA}$ slide ${ }^{-1}$ for $90 \mathrm{~min}$. Rabbit anti-eel serum was used for immunoelectrophoresis of the eel serum fractions and stained with $0.5 \%$ Amido Black $10 \mathrm{~B}$.

Table 1. Anguilla japonica. Percentage of eel serum proteins occurring in various bands obtained on cellulose acetate following electrophoresis

\begin{tabular}{|c|c|c|c|c|c|c|c|}
\hline \multirow{2}{*}{\multicolumn{2}{|c|}{ Immunization group }} & \multicolumn{6}{|c|}{ Band number } \\
\hline & & $\mathrm{Cl}$ & $\mathrm{C} 2$ & $\mathrm{C} 3$ & $\mathrm{C} 4$ & C5 & C6 \\
\hline \multirow{6}{*}{ FKC } & $1 s t w k^{b}$ & - & - & $\begin{array}{l}22.1^{\mathrm{C}} \\
-4.08\end{array}$ & $\begin{array}{l}32.9 \\
\pm 3.38\end{array}$ & $\begin{array}{l}45.1 \\
\pm 6.31\end{array}$ & - \\
\hline & 2nd wk & - & - & - & $\begin{array}{l}57.5 \\
\pm 13.9\end{array}$ & $\begin{array}{l}38.6 \\
\pm 10.3\end{array}$ & - \\
\hline & 3rd wk & - & - & $\begin{array}{l}17.6 \\
\pm 3.12\end{array}$ & $\begin{array}{l}48.0 \\
\pm 17.9\end{array}$ & $\begin{array}{l}38.8 \\
\pm 10.3\end{array}$ & - \\
\hline & 5 th wk & - & - & $\begin{array}{l}22.6 \\
\pm 10.0\end{array}$ & $\begin{array}{l}36.8 \\
\pm 7.41\end{array}$ & $\begin{array}{l}30.2 \\
\pm 6.66\end{array}$ & $\begin{array}{l}10.5 \\
\pm 9.03\end{array}$ \\
\hline & 8th wk & - & - & $\begin{array}{l}19.0 \\
\pm 2.58\end{array}$ & $\begin{array}{l}35.1 \\
\pm 9.67\end{array}$ & $\begin{array}{l}45.9 \\
\pm 8.57\end{array}$ & - \\
\hline & 12 th wk & - & - & $\begin{array}{l}11.5 \\
\pm 0.0\end{array}$ & $\begin{array}{l}37.0 \\
\pm 3.60\end{array}$ & $\begin{array}{l}51.6 \\
\pm 3.60\end{array}$ & - \\
\hline \multirow{6}{*}{ Control } & 1 st wk & - & $\begin{array}{l}3.2 \\
\pm 0.0\end{array}$ & $\begin{array}{l}15.6 \\
\pm 5.32\end{array}$ & $\begin{array}{l}36.1 \\
\pm 3.42\end{array}$ & $\begin{array}{l}45.1 \\
\pm 3.80\end{array}$ & - \\
\hline & 2nd wk & - & - & - & $\begin{array}{l}64.1 \\
\because 16.4\end{array}$ & $\begin{array}{l}30.8 \\
\pm 15.7\end{array}$ & - \\
\hline & $3 r d w k$ & $\begin{array}{l}10.0 \\
\pm 7.00\end{array}$ & $\begin{array}{l}8.7 \\
\pm 1.77\end{array}$ & - & $\begin{array}{l}449 \\
\pm 6.76\end{array}$ & $\begin{array}{l}36.4 \\
\pm 5.92\end{array}$ & - \\
\hline & 5 th wk & - & - & $\begin{array}{l}21.1 \\
\pm 6.13\end{array}$ & $\begin{array}{l}32.0 \\
\pm 2.00\end{array}$ & $\begin{array}{l}46.9 \\
\pm 5.88\end{array}$ & - \\
\hline & 8th wh & - & - & $\begin{array}{l}18.2 \\
\pm 1.52\end{array}$ & $\begin{array}{l}38.4 \\
\pm 2.19\end{array}$ & $\begin{array}{l}40.7 \\
\pm 4.22\end{array}$ & - \\
\hline & 12 th wk & - & - & $\begin{array}{l}9.20 \\
\pm 4.60\end{array}$ & $\begin{array}{l}17.2 \\
\pm 4.84\end{array}$ & $\begin{array}{l}45.7 \\
\pm 6.72\end{array}$ & - \\
\hline \multicolumn{8}{|c|}{$\begin{array}{l}\text { Band numbers are based on the degree of migration from the cathode (band } 6 \text { being the lowest mobility band) } \\
\text { Weeks after injection } \\
\text { Mean percentage } \pm \text { standard deviation. }\end{array}$} \\
\hline
\end{tabular}


A
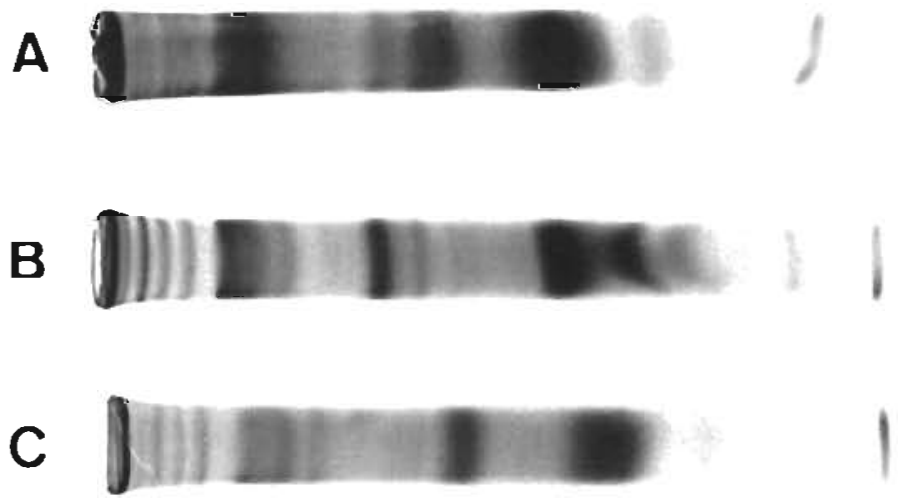

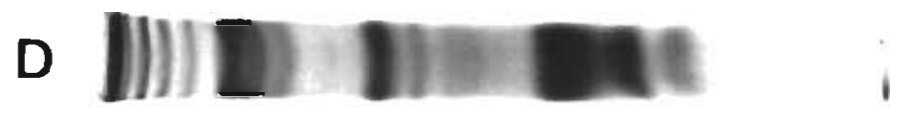

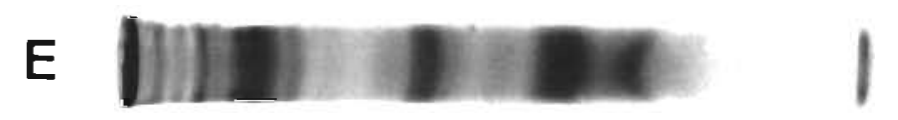

Fig. 2. Anguilla japonica. Polyacrylamide electrophoresis of eel serum on $7 \%$ acrylamide gel. Lanes A, B, C, D: Sera of 4 eels collected 3 wk after immuniza-

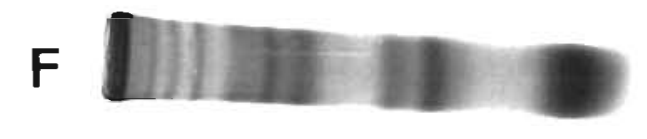
tion. Lanes $E, F$ : Sera of 2 eels collected 3 wk after injection of sterile physiological saline

Fig. 3. Diagram of all precipitin lines observed by immuno-electrophoresis of Anguilla japonica serum

Gel filtration. Three weeks after immunization, gel filtration of pooled eel serum was carried out to separate protein fractions. Sephadex G-200 (Pharmacia Fine Chemicals, Sweden) was equilibrated with $0.01 \mathrm{M}$ phosphate buffer (PB) (pH 7.0) before use. Pooled eel serum $(0.8 \mathrm{ml})$ was applied to a column $(1.5 \times 100 \mathrm{~cm})$

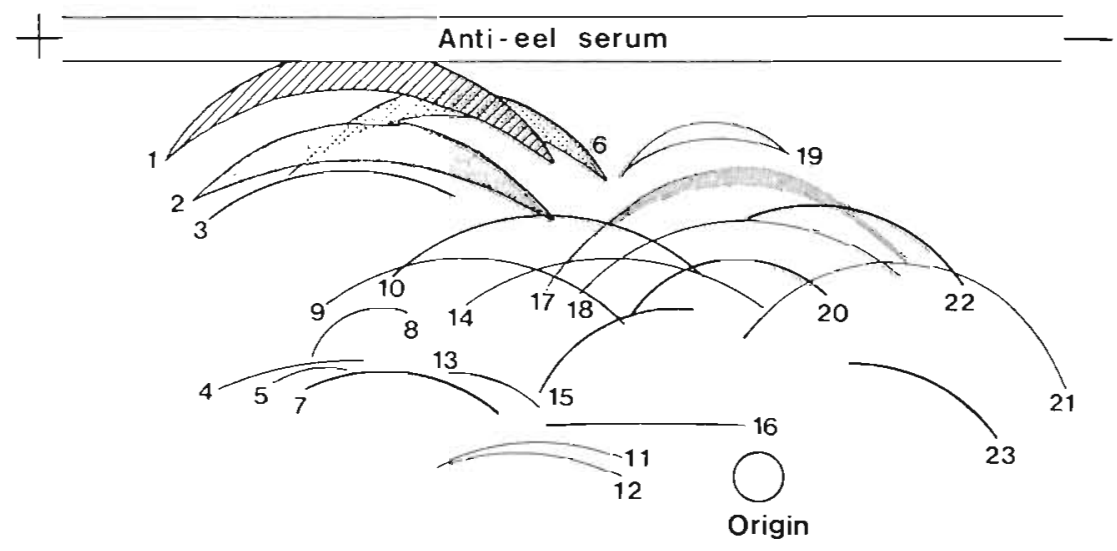

and the serum constituents were eluted with $0.01 \mathrm{MPB}$ at a flow rate of $11.5 \mathrm{ml} \mathrm{h}^{-1}$. Three milliliter fractions were collected and analysed for protein concentration by the microbiuret method of Itzhaki \& Gill (1964). Each fraction was concentrated 10 -fold using polyethylene glycol (PEG) and then dialyzed against distilled 
water. The agglutinating antibody titer of each fraction against formalin-killed Edwardsiella tarda cells was determined by the microtiter plate method. A final concentration of 0.1 M2-mercaptoethanol (2-ME) was mixed with the fraction showing antibody activity and incubated overnight at $4{ }^{\circ} \mathrm{C}$. Following this treatment, the agglutinating antibody titer of the fraction was again determined.

\section{RESULTS}

The changes in the geometric mean agglutinating antibody titer against FKC for immunized and nonimmunized eels are shown in Fig. 1. In the immunized eels, the titer increased sharply over the course of $2 \mathrm{wk}$ and reached a maximum after $3 \mathrm{wk}$ (geometric mean titer $1: 2048$ ).

Electrophoresis of eel serum proteins on cellulose acetate resulted in up to 6 recognizable bands, Bands $\mathrm{C} 1$ and $\mathrm{C} 6$ being the highest and lowest mobility bands, respectively. The percentage of the serum protein occurring in each band is shown in Table 1. C1 and $\mathrm{C} 2$ bands were found only in control sera, while (the lowest mobility) C6 band occurred only in the immunized eel sera at $5 \mathrm{wk}$ after immunization. The $\mathrm{C} 4$ and $\mathrm{C} 5$ bands occurred in all serum samples. These bands were the 2 major bands bound in the serum, accounting for 43.5 and $41.3 \%$ of the total protein, respectively.

Polyacrylamide electrophoresis of eel serum collected $3 \mathrm{wk}$ after immunization resulted in the bands shown in Fig. 2. The banding patterns of serum from immunized fish (taken at various times post-immunization) proved indistinguishable from those of the nonimmunized controls.

A diagram of all the precipitin lines observed in the serum of vaccinated or unvaccinated eels by immunoelectrophoresis is shown in Fig. 3. Twentythree different bands were identified. The bands are numbered according to their mobility, the highest mobility band being assigned the highest number. Six bands (Band 2, 11, 12, 17, 21, and 23) were clearly identified and constantly demonstrated in all samples of eel serum. Band numbers 10, 16, and 20 were not always clearly present but their presence or absence did not appear to be related to whether the eels were immunized or not. No clear differences were seen in the immunoelectrophoretic patterns of eel sera collected at $1,2,3,5,8$, and $12 \mathrm{wk}$ after immunization.

The results of the gel filtration of eel serum on Sephadex G-200 are shown in Fig. 4 along with the agglutinating antibody titers of the resulting fractions. Four fractions (G1-G4) were obtained from the serum of both immunized and non-immunized eels, 3 of the
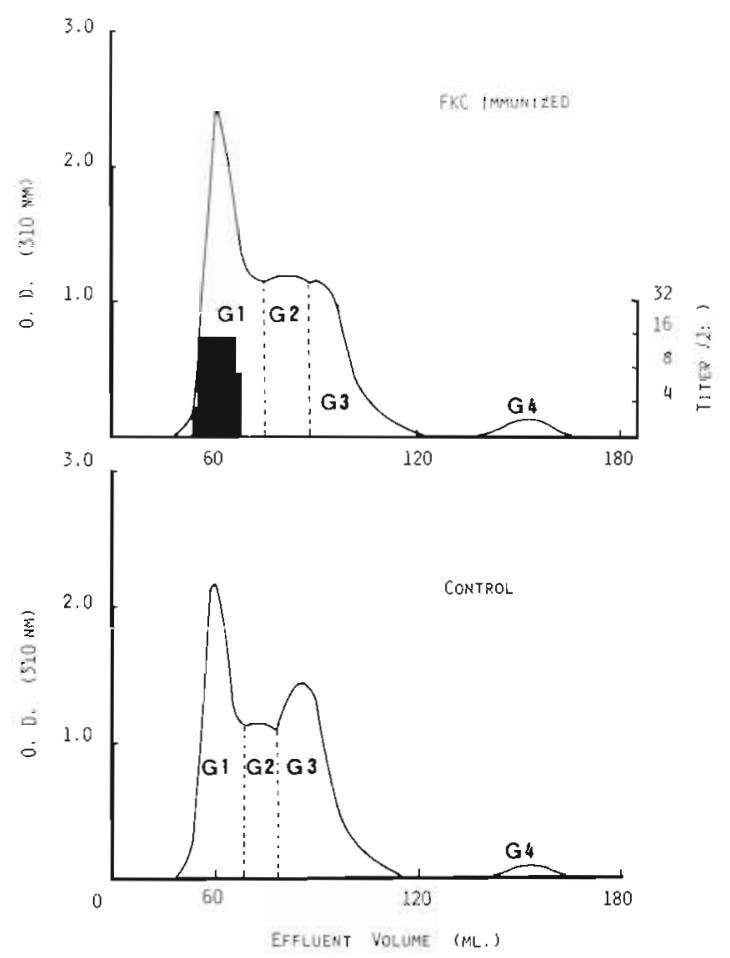

Fig. 4. Gel filtration and agglutinating antibody titer of Anguilla japonica serum on Sephadex G200

fractions being poorly resolved. Only Fraction G1 exhibited agglutinating activity against the pathogen. This activity occurred only in Fraction G1 from the immunized eels and was lost after treatment with 2ME. Polyacrylamide electrophoresis of the fractions separated by gel chromatography resulted in the bands shown in Fig. 5. Electrophoresis of Fraction G1, the fraction containing agglutinating activity, yielded 6 bands with Rf values of 0.03 to 0.20 . After immunoelectrophoresis (Fig. 6), Fraction G1 showed 5 precipitin lines (one of them barely visible) corresponding to 2 , $11,17,20$ and 23 of the whole serum bands. There were no differences between the immunized and nonimmunized eel sera.

\section{DISCUSSION}

This experiment was performed at constant water temperature of $25^{\circ} \mathrm{C}$ which corresponds to the average temperature of eel ponds in Japan. Water temperature is of primary importance because the immune response in fish is temperature-related. In eels it has been demonstrated that agglutinating antibodies are produced at 16 to $19^{\circ} \mathrm{C}$ but not at 7 to $11^{\circ} \mathrm{C}$ (Muroga \& Egusa 1969). The agglutination results reported here are similar to those obtained by Song \& Kou (1981) who obtained a high agglutinating antibody titer by injec- 
tion of FKC and adjuvant. Similarly, Salati et al. (1983) obtained high agglutinating antibody titers by injecting eels with different antigen preparations such as FKC, lipopolysaccharide, or exotoxin.

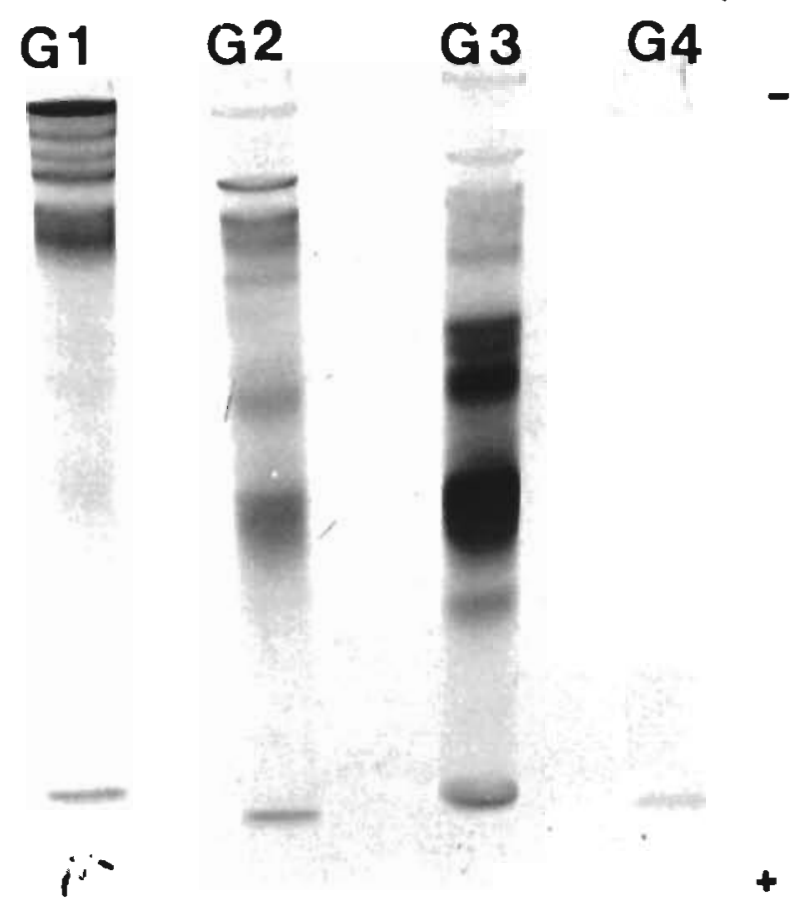

Fig. 5. Disk electrophoresis of Anguilla japonica serum fractions $3 \mathrm{wk}$ after immunization separated by gel filtration on Sephadex G200
In the present study, 6 recognizable bands were obtained by cellulose acetate electrophoresis, 2 of which were obtained constantly (C4 and C5). It is reported $\alpha$ and $\beta$-globulins were observed constantly in the serum of Japanese eels, but the albumin concentration was less than that found in other fish (Nagai \& Sugai 1977). The C4 and C5 bands are probably analogous to the $\alpha$ and $\beta$-globulins, respectively. The C6 band, which has the lowest mobility, was obtained only in immunized eels but the appearance of this band did not correlate directly with the increase of the serum agglutinating antibody titer. Cellulose acetate membrane electrophoresis has been used to analyse the serum of various anadromous and marine fish (Evelyn 1971, Nakagawa 1978, Kusuda \& Fukuda 1980), and differences between immune and non-immune fish sera have been demonstrated by Evelyn (1971) for sockeye salmon Oncorhynchus nerka and by Kusuda \& Fukuda (1980) for yellowtail Seriola quinqueradiata. However, in freshwater fish, such as colored carp Cyprinus carpio immunized with Aeromonas hydrophila FKC, electrophoresis on cellulose acetate did not show differences between immunized and non-immunized fish sera (Kusuda et al. 1987). Similarly in the present study, it was not possible to demonstrate clear electrophoretic differences between immunized and nonimmunized eels.

In the Japanese eel Anguilla japonica 22 precipitin lines were produced by immunoelectrophoresis with an additional low-mobility precipitin line when the eels were immunized by injection with bovine serum albu-
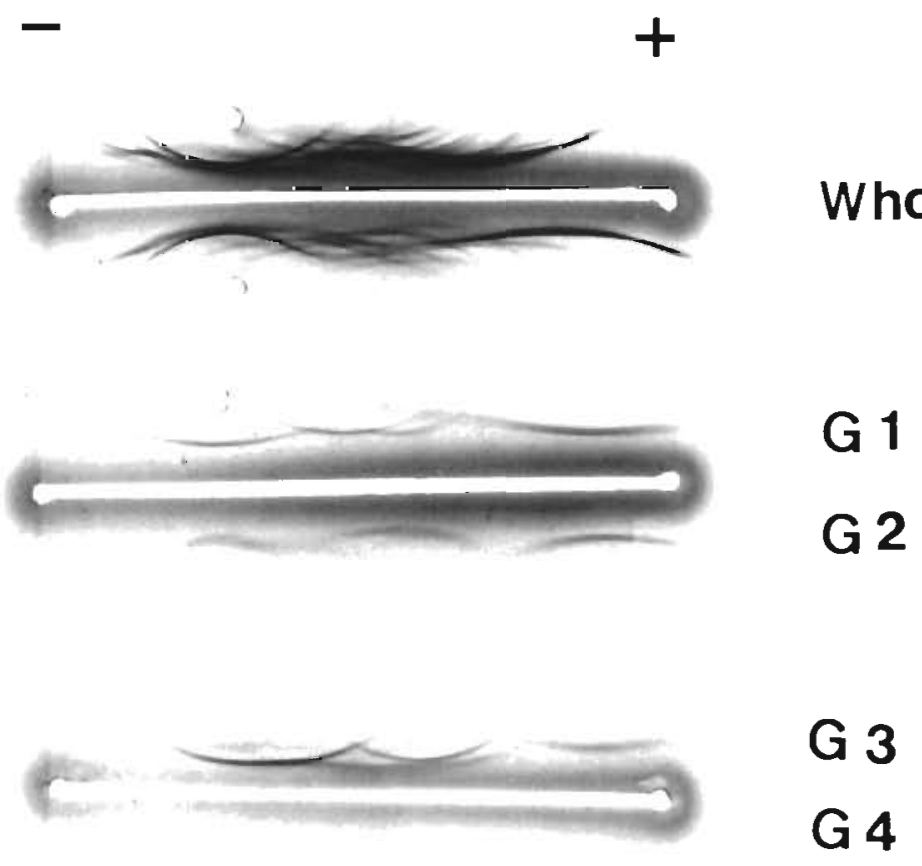

Fig. 6. Immunoelectrophoresis of Anguilla japonica serum fractions $3 \mathrm{wk}$ after immunization and separated by gel filtration on Sephadex G200 
min (Nagai \& Sugai 1977). Though 23 precipitin lines were also observed by immunoelectrophoresis in the present study, a low mobility precipitin line was not produced specifically in the immunized eel serum and it was difficult to distinguish between the sera of immunized and non-immunized eels. The same difficulty was experienced in distinguishing between the sera of immunized and non-immunized eels using polyacrylamide gel electrophoresis. These 3 electrophoretic methods for analysing the serum were not suitable for following the immune response in eels.

In the present study 4 fractions were obtained by gel filtration, but Hara (1975) reported only 3 fractions by gel filtration of Japanese eel serum. In New Zealand eels Anguilla australis the specific agglutinating antibodies were found by gel filtration in the first fraction (McArthur 1978). In this study, the first fraction also showed a strong agglutinating activity. The activity was lost after treatment with $2-\mathrm{ME}$, a substance used to reduce the disulfide bounds of immunoglobulins. This result agrees with reports on other fish where the activity of the immunoglobulins was completely abolished by 2-ME treatment (Evelyn 1971, Clem \& McLean 1975, Ingram \& Alexander 1979). Studies on the separation and purification of other bony fish serum antibodies demonstrated that only the IgM class occurs (Ambrosius et al. 1982). From the results of this study, it is possible to conclude that the Japanese eel possesses an immune system rather typical of other bony fishes, and that the substances having specific agglutinating activity occur in the high molecular weight serum fraction ( $\mathrm{MW}>800000)$, corresponding to human IgM. The possibility that other types of specific antibodies are produced requires further investigation.

\section{LITERATURE CITATION}

Ambrosius, H., Fiebing, H., Scherbaum, I. (1982). Phylogenic aspects of fish immunoglobulins and lymphocyte receptor. Dev. Comp. Immun. 2 (Suppl.): 3-13

Clem, L. W. McLean, W. E. (1975). Phylogeny of immunoglobulins of the margate, a marine teleost fish. Immun. 29: $791-799$

Davis, B. J. (1964). Disk electrophoresis - II. Method and application to human serum proteins. Ann. N. Y. Acad. Sci. 121: 600-601

Evelyn, T P. T (1971). The agglutinin response in sockeye salmon vaccinated intraperitoneally with a heat-killed pre- paration of the bacterium responsible for salmonid kidney disease. J. Wildl. Dis. 7: 328-335

Fine, 1. M., Boffa, G. A., Driphon, A. (1963). The proteins of eel serum; starch gel electrophoresis and immunological studies. Proc. Soc. Exp. Biol. Med. 114: 651-654

Hara, A. (1975). Electrophoretical and immunological studies of fish serum proteins. Nippon Suisan Gakkaishi. 41. 105-113 (Japanese)

Ingram, G. A., Alexander, J. B. (1979). The immunoglobulin of the brown trout, Salmo trutta, and its concentration in the serum of antigen-stimulated and non-stimulated fish. J. Fish Biol. 14: 249-260

Itzhaki, R. F., Gill, D. M. (1964). A micro-biuret method for estimating proteins. Analyt. Biochem 9: 401-410

Kusuda, R., Chen, C. F., Kawai, K. (1987). Changes in the agglutinating antibody titer and serum protein composition of colored carp after immunization with Aeromonas hydrophila. Fish Pathol. 22: 141-146. (Japanese)

Kusuda, R., Fukuda, Y (1980). Agglutinating antibodr titers and serum protein changes of yellowtail after immunization with Pasteurella piscicida cells. Nippon Suisan Gakkaishi. 46: 801-807

McArthur, C. P. (1978). Humoral antibody production by New Zealand eels against the intestinal trematode Telogaster opisthorchis Macfarlane 1945. J. Fish Dis. 1: 377-387

Muroga, K., Egusa, S. (1969). Immune response of the Japanese eel to Vibrio anguillarum - I. Effects of temperature on agglutinating antibody production in starved eels. Nippon Suisan Gakkaishi. 35: 868-874

Nagai, A., Sugai, N. (1977). Immunoelectrophoretic study of plasma protein of Japanese eel, Anguilla japonica. J. Fac. Mar Sci. Technol., Tokai Univ. 9: 109-117. (Japanese)

Nakagawa, H. (1978). Classification of albumin and globulin in yellowtail plasma. Nippon Suisan Gakkaishi. 44: 251-257

Nowotny, A. (1969). Basic exercises in immunochemistry. Springer Verlag, New York, p. 139-143

Orstein., L. (1964). Disk electrophoresis - I. Background and theory. Ann. N. Y Acad. Sci. 121: 321-349

Salati, F., Kawai, K., Kusuda, R. (1983). Immune-response of eel against Edwardsiella tarda antigens. Fish Pathol. 18: 1.35-141

Salati, F., Kawai, K., Kusuda, R. (1984). Immune response of eel to Edwardsiella tarda lipopolysaccharide. Fish Pathol. 19: $187-192$

Salati, F., Kusuda, R. (1985). Vaccine preparations used for immunization of eel Anguilla japonica against Edwardsiella tarda infection. Nippon Suisan Gakkaishi. 51: 1233-1237

Salati, F., Kusuda, R. (1986). Immune response of eel to Edwardsiella tarda lipid. Fish Pathol. 21: 201-205

Song, Y L., Kou, G. H. (1981). The immune-response of eel (Anguilla japonica) against Edwardsiella anguillimortifera as studied by the immersion method. Fish Pathol. 15: 249-255

Wakabayashi, H., Egusa, S. (1973). Edwardsiella tarda (Paracolobactrum anguillimortiferum) associated with pondcultured eel disease. Nippon Suisan Gakkaishi. 39: 931-936 